\title{
54. ELECTRICAL RESISTIVITY MEASUREMENTS OF SEDIMENTS FROM THE BLACK SEA AS A GUIDE TO DIFFUSIVE PROPERTIES
}

\author{
F.T.Manheim, ${ }^{1}$ Department of Marine Science, University of South Florida, St. Petersburg, Florida
}

\begin{abstract}
Formation factor $(\mathrm{F})$ has been measured for Black Sea cores by methods previously developed in the course of the Deep Sea Drilling Project (Manheim and Waterman, 1974). The inverse of $F$ provides a measure of the tortuosity of the sediments with respect to the ability of dissolved species to migrate through interconnected pores. The diffusive permeability of unlithified sediments down to more than 600 meters depth decreases from about one-third to between one-tenth and one-twentieth of that of free solution. Lithified and cemented sediments such as limestones and dolomites in the lowest strata of Sites 380 and 381 display formation factors as high as 500 , or as little as $1 / 500$ th of the diffusive permeability of free solution. Though retaining finite permeability to salt and gas diffusion, such sediments form substantial barriers to migration and permit partial retention of "paleosalinities" in pore fluids where the cementation took place soon after sediment burial.
\end{abstract}

\section{INTRODUCTION}

The ability of sediments to permit ionic and molecular diffusion through interconnected pore spaces is important for salt migration, diagenetic phenomena, and to predict movement of dissolved hydrocarbons such as methane, ethane and $\mathrm{CO}_{2}$. To measure these properties a resistivity probe similar to that employed previously on DSDP legs (Manheim and Waterman, 1974; Manheim, 1974) was utilized.

The method is based on the analogy between the ability of interconnected pores to conduct electricity and their ability to permit diffusion of dissolved species in response to concentration gradients. The chief measurement is the "formation factor":

$$
F=R_{s} / R_{w}
$$

where $R_{S}$ is rock or sediment resistivity and $R_{w}$ is the resistivity of the enclosed pore water at a common temperature.

$$
d=d_{o} k
$$

where $d_{i s}$ is the diffusion coeffieient for a given ion or molecular species in sediments, $D_{O}$ is the coefficient in free solution, and $k=1 / F=$ the "tortuosity factor" measuring the increase in effective path length of diffusion. It should be noted that the diffusion coefficient so measured does not take into account adsorption or reaction effects, fluid movements, or conduction of electricity by the clay matrix of a rock. Normally, the conduction of electricity by the sediment

'Current address: U.S. Geological Survey, Woods Hole, Massachusetts. minerals has not been significant in strata penetrated by DSDP to date. It can be shown by comparing the rate of accumulation of sediments and effective diffusion coefficient in common units that physical convection of fluids owing to consolidation of sediment must be slower, at least in the vertical direction, than movement through molecular diffusion (see Manheim and Schug, this volume). Thus, measurement of diffusive permeability via electrical conductivity (resistivity) methods can provide an effective guide to the behavior of interstitial components with depth.

\section{METHODS}

The details of operation of the measurement system are given in Manheim and Waterman (1974). Briefly, cell constants for the 4-electrode probe are measured in core liner containers on fluid of known resistivity and salinity. The core liner containers are chosen to resemble the configuration of sediment cores in the liners as shown in Figure 1. Electrodes are normally inserted into the ends of the $10-\mathrm{cm}$ sections used for pore fluid analysis before these are placed in the interstitial fluid extraction device. In case of lithified sediments, guide holes are drilled with an electrical drill and carbide-tipped bit through a template matching the electrode spacings. These holes permit insertion of electrodes without rupturing the core, even in very hard sediments. The holes may be moistened with electrolyte if necessary to provide better contact.

Partial immersion of electrodes will increase electrical resistance over full immersion, but this effect can be calibrated as noted in Figure 1.

$$
R_{s}{ }^{\text {corr }}=R_{s}{ }^{\text {app }} \times C
$$

where $C$ is the cell constant. 


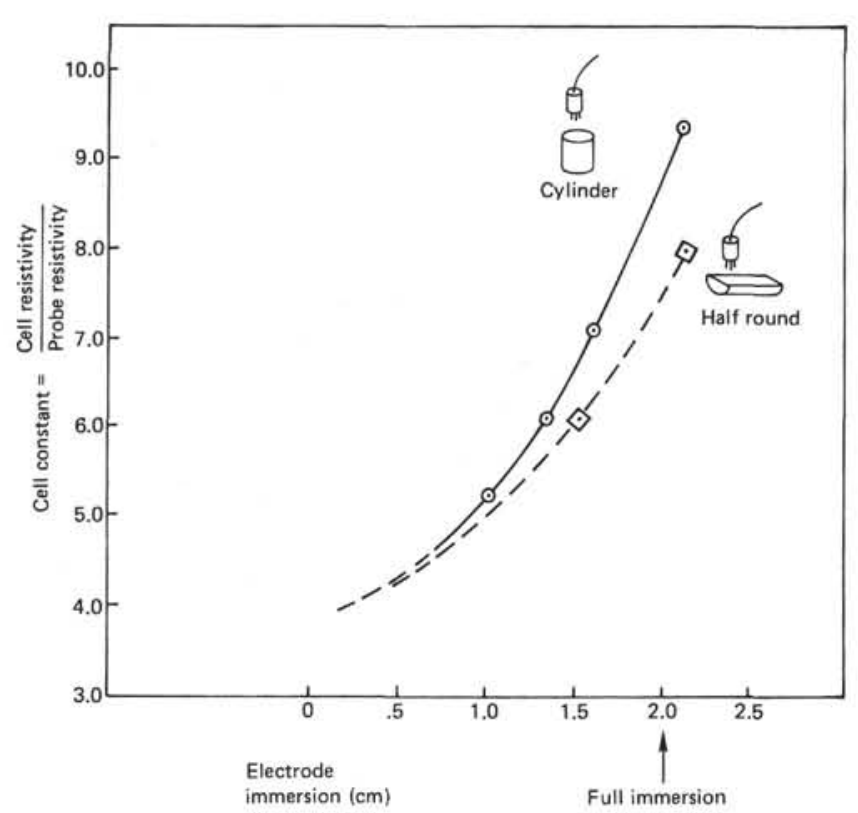

Figure 1. Correction diagram for resistivity measurements on cores (linear inner diameter $=2.56^{\prime \prime}=6.51 \mathrm{~cm}$ ).

These constants must be redetermined regularly. $R w$, or resistivity of pore fluid may be obtained either by direct analysis of pore water in a Schlumberger Well Surveying Co. or other minicell, or by interpolation from a curve established for various "salinities" (by refractive index) and resistivities (Figure 2). Varying ionic relationships will cause deviations from linear relationships, but these are usually reasonably consistent within a given site. Hence, a curve based on a discrete site normally gives results well within the local variability of resistivity, including variation based on orientation of cores. In the present studies, resistivity measurements have been principally made in the horizontal direction, i.e., inserting probes into the ends of cores where disturbance was least.

\section{RESULTS}

Formation factors $(R s / R w)$ where $R s=$ sediment resistivity and $R w=$ pore fluid resistivity tend to increase with depth of sediment burial. This occurs as a result of sediment consolidation, reduction of interconnected pore space, cementation, as well as factors as yet poorly understood.

Data on the trends are given in Tables 1-3, and in Figures 3 and 4 . The tables show that owing to the marked fluctuations in pore fluid salinity in the upper levels of the core holes, $F$ does not correlate well with gross sediment resistivity. With depth, however, diffusion has tended to smooth out changes in composition with depth, and here better relationships are found.

The figures show that the reduction of interconnected pore space indicated by increase in $F$ takes place even though gross porosity does not change significantly. A part of the variation in $F$ can be explained by the presence and distribution of clays. Though clays generally display high porosity, they are generally less permeable by orders of magnitude than coarse clastic

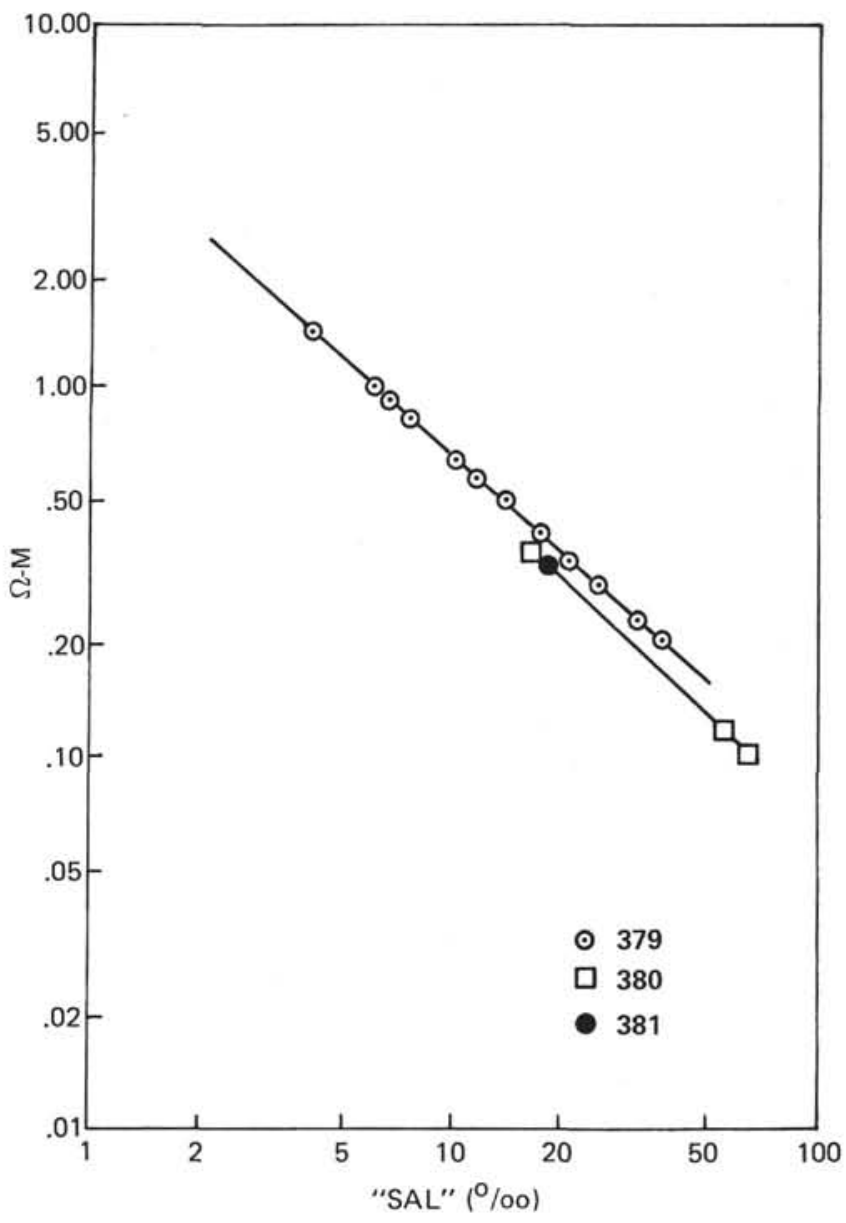

Figure 2. Plot of "salinity" ( $\%$ ) against electrical resistivity for pore fluids, Sites 379, 380, 381.

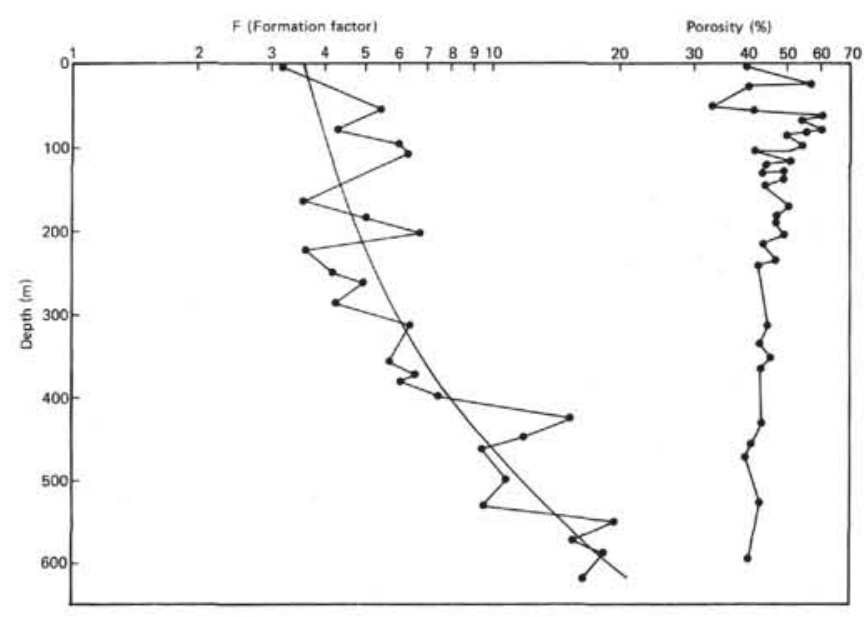

Figure 3. Distribution of formation factor and porosity with depth in Holes $379 \mathrm{~A}$ and $379 B$. Note that both measurements are on the same scale. The heavy dashed line depicts an approximate smoothed depth trend. Porosities are calculated from water content using grain density of 2.67 .

sediments such as sand, that have comparable porosity. This is because their fine grain tends to create highly tortuous structures and fine capillary channels. 
TABLE 1

Electrical Resistivity-Diffusimetry Measurements, Holes 379-379A ${ }^{a}$

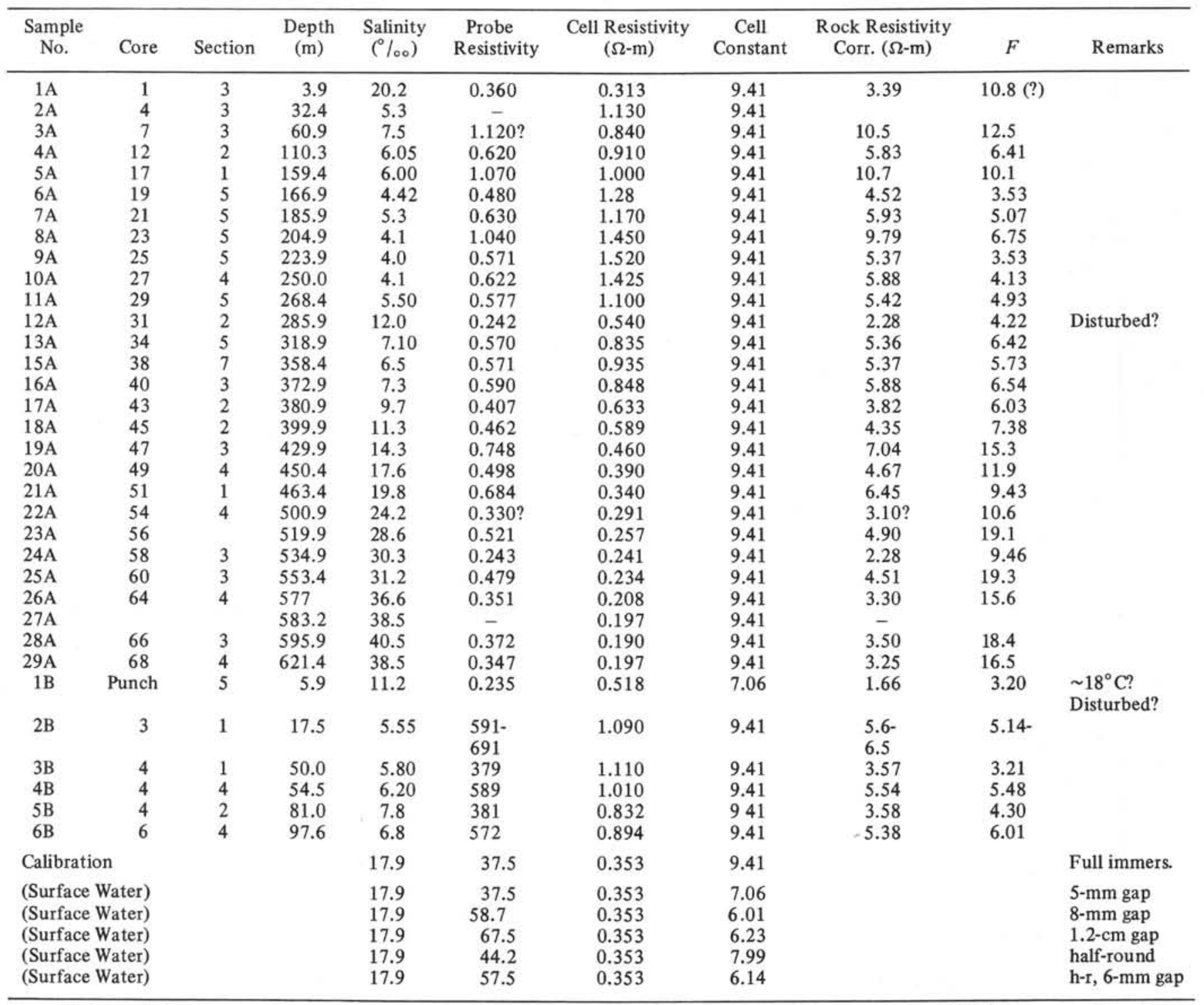

Note: Probe resistivity is given in arbitrary units; cell resistivity refers to interstitial water at lab temperature $\left(23.5^{\circ} \mathrm{C}\right)$ expressed in ohm-m. Cell constant refers to cell resistivity/cup resistivity when cup resembles geometry of sediment. Container is filled with water of known resistivity. True resistivity for sediment $=$ Probe Res. $\times$ Cell constant. $F$ or formation factor is given by rock or sediment resistivity/interstitial water resistivity.

${ }^{\mathrm{a}}$ F. T. Manheim and V. S. Sotelo, analysts.

Although the capillary forces restraining gross fluid movements through sediments do not equally constrict or restrain movement of dissolved species through fine channels, at some point the surficial charged layers of clay platelets are approached. One of the changes occurring with time and loading is the greater approach toward parallel orientation of clays. Bringing clay surfaces closer to each other will tend to obstruct movement of ions by the presence of surface-charged layers.

A second factor affecting diffusive permeability is sorting. Poorly sorted sediments containing clays tend to block channels between larger grains by smaller particles. Thus, we attribute the difference between samples at 204 meters and 223 meters at Site 379 (6.7 and $3.5 F$ values, respectively) to greater sorting and sand content at the latter horizon (Figure 3).

Cementation is an effective method of reducing net porosity of sediments. However, it does not appear to be efficient in reducing the diffusional permeability of sediments until porosity is reduced to low levels. This may be partly attributable to the fact that finer carbonate particles and pore channels appear to be preferentially recrystallized, leaving the larger channels as the last to be sealed. At Sites 380 and 381 lithification and cementation are far advanced in limestones and dolomites at depths of 360 and 900 meters, approximately. At these horizons formation factors of several hundred are typical, whereas shales interbedded with the carbonates have formation factors of only a few 
TABLE 2

Electrical Resistivity-Diffusimetry Measurements, Holes $380-380 \mathrm{~A}^{\mathrm{a}}$

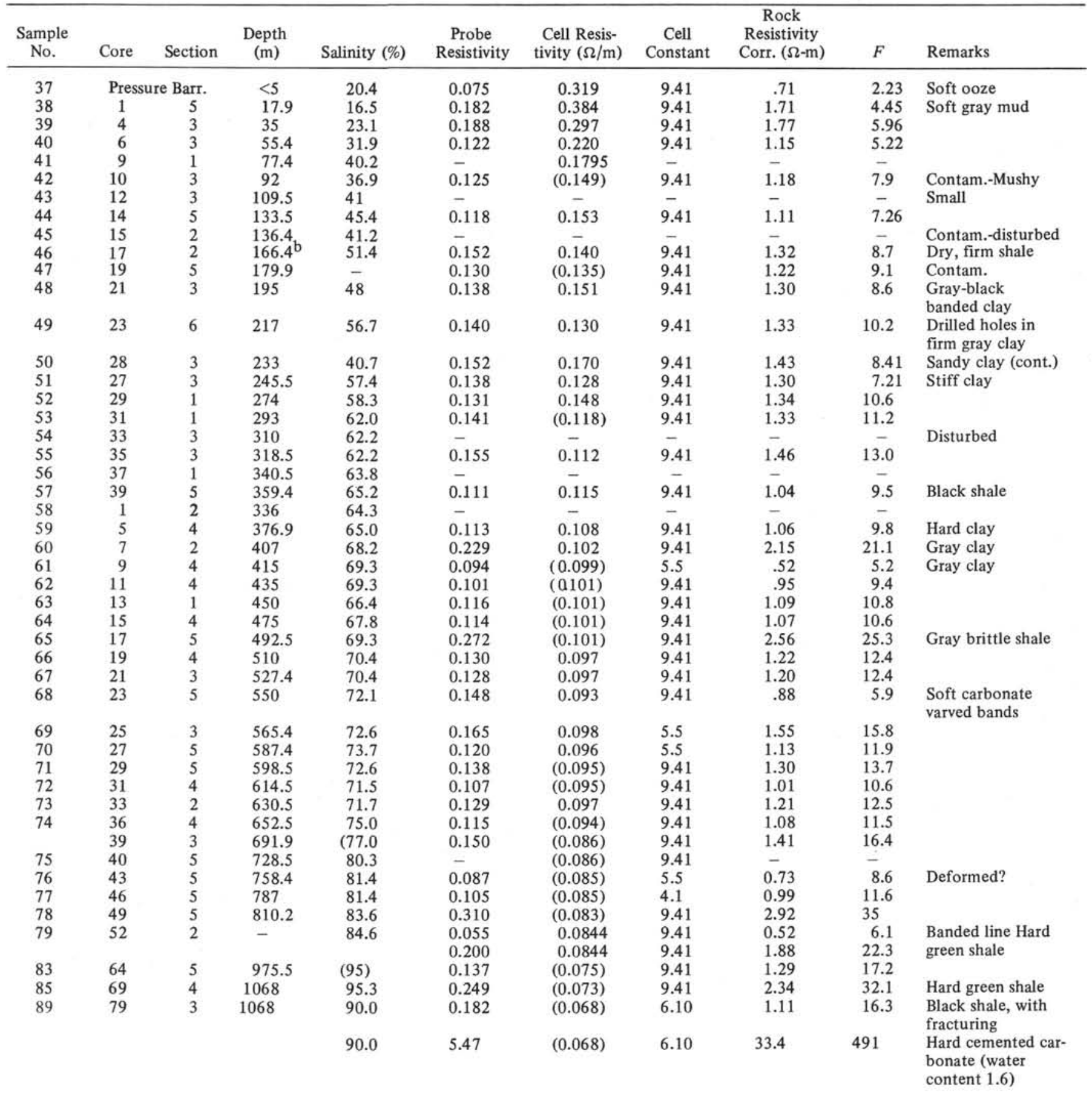

Note: For explanation and notes see Table 1, Site 379, and accompanying text. Parentheses refer to pore fluid resistivities interpolated from curve of resistivity vs. refractive index (Figure 1).

${ }^{\mathrm{a}}$ F. T. Manheim and V. S. Sotelo, analysts.

${ }^{\mathrm{b}}$ From this point and deeper, holes had to be pre-drilled into samples to prevent cracking.

tens. Providing that horizontal continuity of the lithified carbonate beds is maintained, it will not matter much that intervening shales are relatively permeable; the very low porosity carbonates will form effective seals to all but slow diffusion or movement along fracture channels.

\section{DISCUSSION}

Key questions related to formation factor measurements are the extent to which diffusive permeabilities affect ion and gas concentrations in the pore fluids of the rocks. Can paleosalinities be preserved long enough 
TABLE 3

Electical Resistivity-Diffusimetry Measurements, Site $381^{\mathrm{a}}$

\begin{tabular}{|c|c|c|c|c|c|c|c|c|c|c|}
\hline $\begin{array}{l}\text { Sample } \\
\text { No. }\end{array}$ & Core & Section & $\begin{array}{c}\text { Depth } \\
(\mathrm{m})\end{array}$ & Salinity $(\%)$ & $\begin{array}{c}\text { Probe } \\
\text { Resistivity }\end{array}$ & $\begin{array}{l}\text { Cell Resis- } \\
\text { tivity }(\Omega-\mathrm{m})\end{array}$ & $\begin{array}{c}\text { Cell } \\
\text { Constant }\end{array}$ & $\begin{array}{c}\text { Rock } \\
\text { Resistivity } \\
\text { Corr. }(\Omega-\mathrm{m})\end{array}$ & $F$ & Remarks \\
\hline 91 & $1-$ & 2 & 0.30 & 26.9 & 0.0805 & 0.260 & 9.41 & 0.76 & 2.92 & \\
\hline 92 & 2 & 2 & 17.4 & 28.6 & 0.109 & 0.257 & 9.41 & 1.03 & 3.99 & \\
\hline 93 & 3 & 3 & 27.0 & 39.6 & 0.065 & 0.180 & 9.41 & 0.61 & 3.40 & \\
\hline 94 & 5 & 2 & 43.0 & 56.1 & 0.070 & 0.126 & 9.41 & 0.66 & 5.22 & \\
\hline 95 & 7 & 5 & 65.0 & 59.4 & 0.051 & 0.119 & 9.41 & 0.48 & 4.03 & \\
\hline 96 & 9 & 5 & 84.0 & 64.4 & 0.078 & 0.107 & 9.41 & 0.73 & 6.86 & \\
\hline 97 & 12 & 4 & 111.0 & (64) & 0.079 & $0.139-0.108$ & 9.41 & 0.74 & 6.88 & \\
\hline 98 & 14 & 5 & 133.0 & 59.4 & - & 0.113 & 9.41 & - & - & \\
\hline 100 & 16 & 5 & 171.0 & 62.7 & 0.079 & 0.110 & 9.41 & 0.74 & 6.76 & \\
\hline \multirow[t]{2}{*}{103} & 25 & 3 & 225.0 & 63.6 & 0.137 & 0.109 & 9.41 & 0.129 & 11.8 & Horizontal \\
\hline & & & & & 0.175 & 0.108 & 8.00 & 0.140 & 12.8 & Vertical \\
\hline 105 & 27 & 2 & 264.5 & 64.6 & 0.071 & 0.108 & 9.41 & 0.67 & 6.19 & \\
\hline 107 & 31 & 4 & 301.0 & 66.0 & 0.073 & 0.108 & 9.41 & 0.69 & 6.36 & \\
\hline 108 & 33 & 4 & 321.5 & 64 & 0.076 & 0.108 & 9.41 & 0.72 & 6.62 & \\
\hline 109 & 35 & 5 & 336.0 & 65.5 & 0.128 & 0.108 & 9.41 & 1.20 & 11.15 & \\
\hline 110 & 37 & 2 & 399.0 & 64.8 & 0.104 & 0.108 & 9.41 & 0.98 & 9.06 & Shale \\
\hline 110 & 37 & 2 & 399.0 & $(65)$ & 7.06 & 0.108 & 3.92 & 27.68 & 2.56 & $\begin{array}{l}\text { Cemented } \\
\text { limestone }\end{array}$ \\
\hline 112 & 48 & 5 & 472.0 & 39.4 & 0.182 & 0.182 & 9.41 & 1.90 & 10.4 & \\
\hline 113 & $51-$ & 4 & 492.4 & 38.5 & 0.198 & 0.186 & 9.41 & 1.86 & 10.0 & Top \\
\hline 113 & 51 & 4 & 492.4 & 38.5 & 0.225 & 0.186 & 9.41 & 2.12 & 11.4 & Side \\
\hline
\end{tabular}

Note: See Table 1 for notes.

${ }^{\mathrm{a}}$ F. T. Manheim and V. S. Sotelo, analysts.

to account for the Mediterranean-type salinities observed near the bottom of Site 381? Can permeability barriers allow significant gas buildups to occur? Can one set limits on the original salinities in strata?

Quantitative calculations for the latter will require better dating control than is at hand at this writing. However, some limits can be set for the former two questions. Were the lithified carbonates fractured in such a way as to permit long-distance transport of Bosporus waters into the Deep Basin, one might anticipate a more seawater character in ionic composition. However, waters in the deepest horizons of Site 381 show typical "deep basin" diagenesis, with $\mathrm{SO}_{4}$ absent (except for traces), $\mathrm{K}$ and $\mathrm{Mg}$ strongly depleted, and calcium enriched (Manheim and Schug, this volume). In addition, the lithified dolomites and limestones at Site 381 show a breccia-puddingstone texture that suggests early lithification soon after burial. Such lithification would help seal off waters of more normal marine composition (below) from the various salinity regimes that would occur later in Black Sea history. The formation factors ranging from 256 to 500 or more apply to rocks having a water content of $1 \%-5 \%$. One should point out that these determinations were made on hard core fragments wedged in the core catcher of otherwise empty barrels, in most cases. We may assume that the strata in question consist of alternating hard and softer layers, based both on drilling time logs, and on the typical pattern of very poor recovery in such configurations of material. Continuously hard rocks such as limestones generally give far better recovery.

Regarding gaseous diffusion, one may note that at the base of Site 380 a rather sudden increase of heavier hydrocarbons (ethane and higher alkanes) is obtained (Schmitt, this volume). Though the poor-recovery, lithified carbonate layer is considerably less lithified

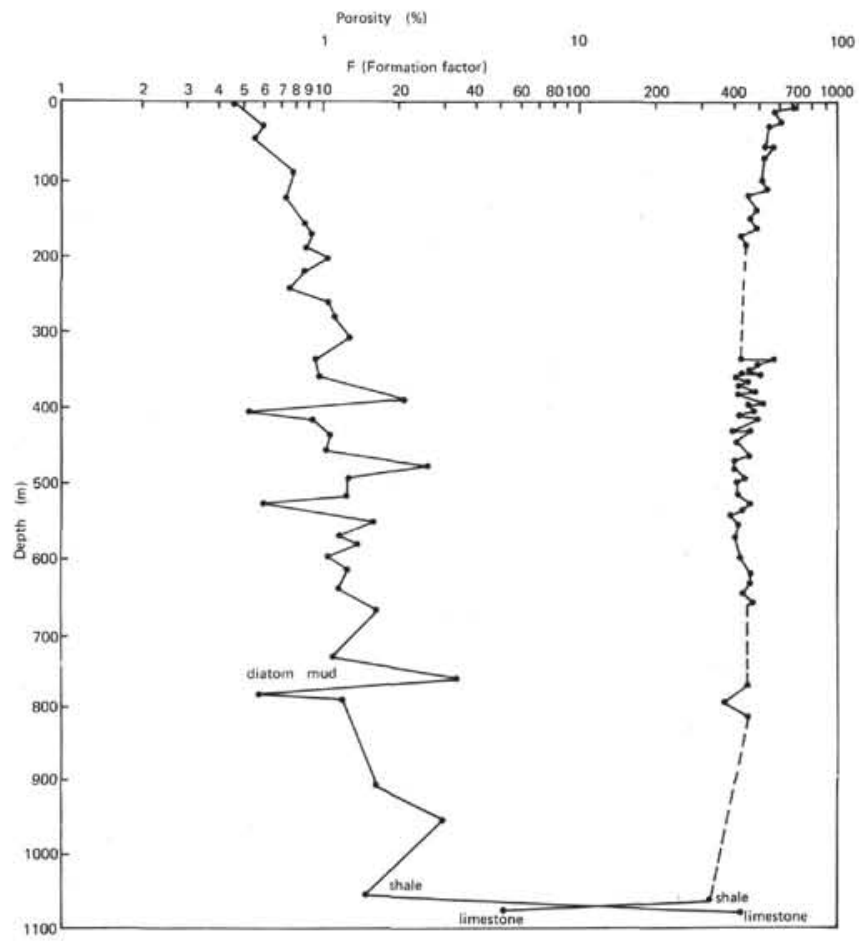

Figure 4. Distribution of formation factor and porosity with depth for Holes 380 and 380 A. Porosities are derived from water content assuming a grain density of 2.67 . Note that a smaller logarithmic scale is used to accommodate the larger variability than in Figure 3. The last data point (deepest) has been extended slightly deeper than its true position near 1060 to obtain visual separation of the shale and the dolomite.

than at Site 381, it nevertheless appears to form enough of a seal to have retarded the movement of heavier hydrocarbons upward and concentrate them to a considerable degree below the poorly permeable forma- 
tions. It is quite possible that greater concentrations of hydrocarbons might be accumulated in updip trap closures, if the lithified carbonate sequences are continued.

\section{REFERENCES}

Manheim, F.T., 1974. Red Sea geochemistry. In Whitmarsh, R.B., Weser, O.E., Ross, D.A., et al., Initial Reports of the Deep Sea Drilling Project, Volume 23: Washington (U.S. Government Printing Office), p. 975-998.

Manheim, F.T. and Waterman, L.S., 1974. Diffusimetry (diffusion constant estimation) on sediment cores by resistivity probe. In von der Borch, C.C., Sclater, J.G., et al., Initial Reports of the Deep Sea Drilling Project, Volume 22: Washington (U.S. Government Printing Office), p. 663-670. 